University of Wollongong

Research Online

Faculty of Business - Papers (Archive)

Faculty of Business and Law

$1-1-2016$

Framing the usefulness of eHRM in talent management: A case study of talent identification in a professional services firm

Sharna L. Wiblen

University of Sydney, swiblen@uow.edu.au

Follow this and additional works at: https://ro.uow.edu.au/buspapers

Part of the Business Commons

Research Online is the open access institutional repository for the University of Wollongong. For further information contact the UOW Library: research-pubs@uow.edu.au 


\title{
Framing the usefulness of eHRM in talent management: A case study of talent identification in a professional services firm
}

\author{
Abstract \\ As talent management evolves from intuitive to evidence-based decision-making, the role of electronic \\ Human Resource Management (eHRM) to gather, distribute, and analyze data becomes more critical. \\ However, surprisingly few academic studies investigate the role of technology in talent management. \\ Drawing on a qualitative case study of talent management in a large professional services firm, this paper \\ critically examines how eHRM information technologies are framed as useful within talent identification \\ discourses. The findings reveal two distinct but interrelated sets of processes employed to identify talent \\ and suggest that the perceived usefulness and centrality of eHRM are influenced by how stakeholders \\ shape their understanding of effective talent management.

\section{Disciplines \\ Business}

\section{Publication Details} \\ Wiblen, S. (2016). Framing the usefulness of eHRM in talent management: A case study of talent \\ identification in a professional services firm. Canadian Journal of Administrative Sciences, 33 (2), 95-107.
}




\title{
Framing the Usefulness of E-HRM in Talent Management: A Case Study of Talent Identification in a Professional Services Firm
}

\begin{abstract}
As talent management evolves from intuitive to evidence-based decision-making, the role of electronic Human Resource Management (e-HRM) to gather, distribute and analyze data would seem to be more critical. However, surprisingly few academic studies investigate the role of technology in talent management. Drawing on a qualitative case study of talent management in a large professional services firm, this paper critically examines how e-HRM information technologies are framed as useful within talent identification discourses. The findings reveal two distinct, but interrelated sets of processes employed to identify talent and suggest that the perceived usefulness and centrality of e-HRM is influenced by how stakeholders shaped their understanding of information technology in talent management.
\end{abstract}

\section{Keywords}

Talent management, electronic Human Resource Management (e-HRM), discourse analysis, talent identification, qualitative case study 


\section{Introduction}

Advocates of e-HRM (Electronic Human Resource Management) posit that information systems will increase the ability to select, retain and manage talent more effectively through the provision of dynamic, real-time data, metrics and analytics (Lawler, Levenson, \& Boudreau, 2004; Williams, 2009). As organizations increasingly recognize the value of effective talent management practices that are informed by data and analytics rather than intuition, the need to understand the role of information technology becomes more pertinent (Davenport, Harris, \& Shapiro, 2010). Many promote the assertion that talent management can benefit from the technological capabilities that support and enable human resource management activities within and across organizational boundaries (Marler \& Fisher, 2013). We know little, however, about how organizations use the capabilities embedded in e-HRM information technologies whilst undertaking talent management, and more specifically talent identification.

This study employs discourse analysis as the theoretical and methodological approach to understand how an organization uses e-HRM capabilities within talent identification processes. The view of discourse adopted by this study, is influenced by the assumption that discourses influence an individual's experience or subjectivity and that their ability to think, speak and act has implications for practices and interactions within organizations (Hardy \& Phillips, 2004). Discourses refer to a 'system of statements which constructs an object' (Parker, 1992:5) which 'cohere in some way to produce both meanings and effects in the real world' (2001:268) and in terms of particular practices and actions (Phillips, Lawrence, \& Hardy, 2004). In other words, discourses 'do not just describe things; they do things' (Potter \& Wetherell, 1987:6) and allow people to make sense of the world by giving it meanings which generate particular experiences and practices (Fairclough, 1992; van Dijk, 1997). According to this approach, discourses are not only associated with the production, 
transmission and consumption of texts, but 'also constitutes power relations by holding in place meanings associated with concepts, objects and subject positions, which distribute power and privileges among actors' (Hardy \& Phillips, 2004:300). Discourse analysis can help to inform our understanding of how organizations use e-HRM capabilities whilst identifying talent for it assumes that the meanings attributed to concepts such as 'talent', 'talent management', 'talent identification' and 'e-HRM', do not exist 'out there' but rather need to be attributed meanings by different stakeholders with different views and interests (Grant \& Marshak, 2011; Hardy, Lawrence, \& Grant, 2005). This creates a situation whereby an array of stakeholders, including individual executives or business units, engage in discursive activity and access an array of discourses to generate new meanings that help - or hinder - the enactment of particular talent management practices. By investigating the discourses that executives and business units, construct around the processes of talent identification, the study is able to acknowledge and appreciate the complexity and ambiguity which encompassed the perceived usefulness of e-HRM in this specific talent management practice.

This paper draws upon an in-depth qualitative case study of a professional services firm operating in Australia - referred to as PSF - to critically examine how e-HRM information technologies were framed as useful within talent identification discourses. The findings illustrate that there were divergent opinions about the usefulness of e-HRM, and more specifically the role of metrics and analytics in evaluating the performance and potential of employees. Two distinct approaches to talent identification are represented through contrasting discourses: referred to as 'measuring' and 'observing' talent. This divergence has interrelated effects on the perceived usefulness of e-HRM in these processes as stakeholders debated whether the identification of talent via performance and potential 
measures, facilitated via information technology would, when enacted, help or hinder talent identification.

By investigating the discourses that executives construct around the processes of talent identification, the study is able to acknowledge and appreciate the complexity and ambiguity which encompassed the perceived usefulness of e-HRM in this specific talent management practice. In doing so, this study contributes to knowledge of e-HRM in a number of significant ways. First, it connects the literature on talent identification within the talent management literature to e-HRM. Second, Marler and Fisher (2013:18) acknowledge that 'theoretical and empirical research in this area is still at an early stage' and this study responds to this challenge by providing a discursive framework within which the subsequent contributions can be located and contextualized. Thirdly, by critically examining the discourses that frame and influence talent identification practices it illustrates how the interactions between the technology and the users shaped the understanding and enactment of e-HRM in talent management.

\section{The Relationship between e-HRM and Talent Management}

Industry and practitioner surveys continually report that talent management is important to, and a challenge for, CEO's and organisations (for example see PwC, 2014; Towers Watson, 2010; Wilson, 2010). Others similarly profess its importance by declaring that talent management can contribute (positively) to the organization and firm performance (Capelli, 2008; Collings \& Mellahi, 2009; Iles, Chuai, \& Preece, 2010; Thunnissen, Boselie, \& Fruytier, 2013a, 2013b). The synthesis of these broader discourses contributes to a salient and normative assumption that the effective management of people is of critical importance to all organizations, regardless of size, or industry, because "talent" is a source of competitive advantage that acts as a weapon to fight the corporate landscape (Chambers, Foulton, 
Handfield-Jones, Hankin, \& Michaels Ill, 1998; Tarique \& Schuler, 2010; Wellins \& Schweyer, 2007).

While the term talent management may be used to refer to HR practices or the establishment of talent pools to facilitate succession planning (Lewis \& Heckman, 2006), within the context of this study, it refers to the identification, development, appraisal, deployment and retention (McDonnell, 2011) of talented employees. Talent management advocates argue that talent management encompasses more than just traditional HR practices such as recruitment, leadership development and succession planning, because it is futureorientated and aligned with strategic goals (Lewis \& Heckman, 2006; Schweyer, 2004). The strategic ambitions of an organization must be the starting point for establishing a set of policies and practices which endeavor to effectively manage those employees who will contribute, unequally, to the realization of the strategy. These policies and practices do not apply to all employees because workforce differentiation is the key attribute of talent management (Beechler \& Woodward, 2009).

In order to manage "talent" effectively and ensure that the most valuable employees are retained, organizations are required to identify talent (Hartmann, Feisel, \& Schober, 2010) and then to engage in practices designed to extract strategic value from these employees, because the 'availability of talent per se is of little strategic value if it is not identified...' (Mellahi \& Collings, 2010:5). In order to identify talent effectively, organizations should have an understanding of whom and what is a talent. Rather than there being a single or universally accepted definition (Tansley, 2011; Thunnissen et al., 2013a, 2013b), there is a multiplicity of views with numerous scholars offering various, and at times conflicting, definitions of this concept. Rather than seeking to reconcile these debates, it is argued that the concept of talent is socially constructed and defined within organizational boundaries. On this basis, organizations are able to establish, through a process of negotiation, whether the term 
"talent" is indicative of certain individual employees (Blass, 2007; Jones, Whitaker, Seet, \& Parkin, 2012; Whelen \& Carcary, 2011); valuable skills and capabilities (McDonnell, Lamare, Gunnigle, \& Lavelle, 2010; Wiblen, Dery, \& Grant, 2012; Wiblen, Grant, \& Dery, 2010); pivotal roles and positions (Boudreau, 2003; Collings \& Mellahi, 2009; Mellahi \& Collings, 2010); or its entire workforce (Thunnissen et al., 2013a).

Operating in parallel to these discourses is the assertion that e-HRM information technologies - the configurations of computer hardware, software, and electronic networking resources that enable intended or actual HRM activities through individual and group-level interactions within and across organizational boundaries (Marler \& Fisher, 2013:21) - are beneficial for talent management. In addition to literature which declares that information technologies can be perceived as useful as individuals believe that using a particular (newly implemented) system would enhance job performance (Davis, 1989; Davis, Bagozzi, \& Warshaw, 1989; Marler, Fisher, \& Ke, 2009; Venkatesh, Morris, Davis, \& Davis, 2003), advocates of e-HRM proclaim that such platforms enhance the efficient and effective management of human resources (Farndale, Paauwe, \& Hoeksema, 2009; Ruël, Bondarouk, \& Looise, 2004; Schalk, Timmerman, \& den Heuvel, 2013; Stone \& Dulebohn, 2013). This is achieved through the standardization and harmonization of the Human Resource (HR) function, which, in turn facilitates faster and more accurate decision-making processes (Parry \& Tyson, 2011; Ruël et al., 2004; Schalk et al., 2013). Such functionality is of importance to transformational activities such as talent management (Parry \& Tyson, 2011; Thite \& Kavanagh, 2009), as e-HRM can enhance decision-making about "talent" by providing stakeholders with access to data. This enables evidence-based decisions and help '... HR practitioners develop greater objectivity and balance in their decisions' (Rousseau \& Barends, 2011:233). 
Within the emerging talent management literature, talent identification processes can be categorized into three approaches, with an employee identified as a talent subject via processes that are either intuitive, individualized, or systematic. The first approach, involves the identification of talented employees via processes that are unstructured and informal. The determination of whether an individual employee is talent resides upon the intuitive or 'gutfeel' opinions of executives undertaking the evaluation. The intuitive approach is heavily criticised. Highhouse (2008) argues that the notion of intuitive experience, whereby HR professionals and other key stakeholders can predict human behavior and an employee's likelihood of success, is a myth. Dries (2013) similarly notes that processes founded upon conjectural assumptions, or conducted without formal assessment policies, can overestimate the validity of intuitive judgments and may privy a 'similar-to-me bias'(i.e. a preference for employees more similar to oneself). Talent identification through such processes, therefore, are deemed of little strategic value to organizations, because identifying talent based on '... instinct and intuition [is] not only inadequate but reckless' (Bassi \& McMurrer, 2007:9).

Jones et al. (2012) offer two distinct and competing approaches to talent management: an individual or system-level. The individualistic approach focuses on single individuals, who may be 'stars' or employees who possess certain valuable tactical and/or operational skills. Talent subjects are identified via processes that do not require formal assessment policies or an understanding of the defining characteristics of talent. This approach essentially views talent as a form of human capital and fails to consider contextual factors (Iles et al., 2010; Jones et al., 2012; McDonnell, 2011). HR practitioners are often advocates of individualistic processes because they believe that certain employees possess an 'X-factor' or the 'right-stuff' (Dries, 2013) and therefore more analytical approaches are unnecessary.

The vast majority of talent management publications advocate for strategic and systems approaches founded upon the assertion that systematic, integrated and proactive 
(Collings, McDonnell, \& Scullion, 2009; Collings \& Mellahi, 2009; Mellahi \& Collings, 2010) processes are the most effective. From this perspective all employees are subjected to the same set of processes (Iles et al., 2010; Stainton, 2005). The foundation a strategic approach should be the identification of key positions which should be filled with A performers (Huselid, Beatty, \& Becker, 2005; Mellahi \& Collings, 2010).

Associated with each set of processes is a role for e-HRM. For the intuitive approach, the role of technology appears to be irrelevant at best, whilst the systematic approach posits that the capabilities of e-HRM are useful as they establish boundaries around talent identification and support the consistent evaluation of employees across an organization (Stahl et al., 2007). Put another way, it is the way that practices are formed through the appropriation of e-HRM capabilities that processes of identifying talent are formalized, structured, and standardized (Parry \& Tyson, 2011; Ruël et al., 2004; Schalk et al., 2013).

It is also here that discourses pertaining to the importance of talent management metrics, data and analytics become prominent. Boudreau and Ramstad, via their "decision science" approach, posit that data will provide a logical, reliable and consistent - but flexible framework to enhance decisions about a key resource (2002). Similar sentiments are mirrored by Bassi and McMurrer (2007) and Williams (2009) who profess the usefulness of e-HRM as it affords the capabilities to generate data, information and knowledge about talent, which is vital for achieving competitive advantage. Davenport et al. (2010) argue that leading-edge companies are increasingly adopting sophisticated data collection technology to evaluate employees and suggest, 'If you want better performance from your top employees - who are perhaps your greatest asset and your largest expense - you'll do well to favor analytics over your gut instincts' (2010:2). Evaluations based upon metrics, or 'hard' performance data are also less politically charged (Dries, 2013). 
Despite substantial agreement that e-HRM can provide sophisticated and standardized metrics there are concerns about whether the adoption of a systematic approach will result in the identification of "talent clones" (McDonnell, 2011). By prioritizing homophily at the expense of the ability to recognize idiosyncratic characteristics and attributing value to difference and diversity (Highhouse, 2008; Mäkelä, Björkman, \& Ehrnrooth, 2010), we may well be restricting our perceptions of talent. Furthermore, there is also the danger that standardizing interactions through e-HRM may also result in the 'McDonaldization' or ‘commodification' of language (Francis, Parkes, \& Reddington, 2014; Heller, 2003) where professional judgments are reduced to standardized interactions and a 'tick box' mentality (Vorster, 2008). Reservations about a systematic approach are acknowledged by strategic talent management scholars, including Mellahi and Collings, who '... contend that this line of thinking can be misleading when applied to managing talented people. Talent is often tacit, inherently complex and difficult to measure because it often deals with potential rather than performance' (2010:147).

While there are a number of publications that discuss the importance of identifying talent, our understanding of how organizations conduct this process are lacking (McDonnell, 2011) with only a few studies (for example see Jones et al., 2012; Wiblen et al., 2012) empirically examining the social processes deployed to identify talent subjects. In addition, while e-HRM is considered to have critical capabilities for a more systematic approach to talent identification through the generation of data and information, additional theory and research is also needed to understand how information technology informs these practices (Stone \& Dulebohn, 2013). The aim of this study is therefore, to begin to understand how the meanings of e-HRM information technologies and talent are negotiated, and how these meanings influence how e-HRM is perceived and utilized within talent management 
practices. This is achieved via an exploratory case study which investigates the talent identification processes of a professional services firm.

\section{Research Site and Methods}

This study forms part of a larger research project examining talent management in Australian organizations. This specific study is exploratory and aims to contribute to knowledge of eHRM and talent management. A qualitative approach involving a detailed case study of talent identification processes was adopted to investigate a phenomena that are currently poorly understood (Maguire \& Phillips, 2008; Marshall \& Rossman, 1995) and requires examination of an array of mechanisms and contextual factors that potentially influence talent management practices (Björkman, Smale, Sumelius, Suutari, \& Lu, 2008; Hartmann et al., 2010). The site for this study - PSF (a pseudonym) - was selected due to its reliance on knowledge-based employees 'who use their heads more than their hands to produce value' (Horibe, 1999:xi). PSF is committed to the effective identification and management of talent and recognizes that employees 'lie at the heart of talent management' (McDonnell et al., 2010:151).

The findings presented derive from data collected over a three-year period commencing in January 2010 via publicly available data (contextual information) and semistructured interviews (January 2010 - August 2011). Interviews were conducted with executives located in PSF's corporate HR function because they were responsible for the creation and management of practices delivered organization-wide. This rationale was informed by, and aligned with, research that suggests HR functions play a key role in talent management (Calo, 2008; CIPD, 2006; Devine \& Powell, 2008). Discussions with interviewees focused on the context of the organization, including its current and future strategic ambitions, client offerings, as well as the practice of talent management and talent identification, at the business unit and organizational level. A second round of interviews was 
conducted with executives located within PSF's six business units, and focused on deriving insights into the specific talent identification practices enacted within these units. Overall a total 79 interviews with 44 executives were conducted which resulted in 70 hours of interview data, all of which were transcribed, reviewed and then subsequently analyzed (Roulston, deMarrais, \& Lewis, 2003).

Discourse analysis was the primary methodological approach employed to examine the data via four main stages. In this context, discourses comprised three interrelated elements that act to reproduce or transform discourses pertaining to e-HRM and talent management. These were written, verbal and visual texts, discursive practices and the material and social practices which may potentially shape the composition of a discourse (Fairclough, 1995; Francis et al., 2014).

In the first stage, an event history database was constructed (Van de Ven \& Poole, 1990). This involved chronologically ordering the data according to its source and genre (e.g. interview transcripts, interview notes, audio recording of interview, website, company documentation, informal meeting, internal or external presentation, non-participant observation). This data were further organized into a discursive event history database (Maguire, 2004) which sought to capture who said what and when (Maguire \& Hardy, 2009). As such the same data was categorized according to the functionality and the location of the interviewee who generated the data. For example, distinctions were made between executives located within and outside of the HR function and whether their role was responsible for the creation and delivery of practices organisation-wide (referred to as Corporate executives) or within a specific division, known as 'business units' (referred to as Business Unit executives). This analysis considered how the concepts of talent management and e-HRM were negotiated and constituted in discourse. The second stage involved content analysis, where the data were subjected to a detailed and systematic examination and interpretation in 
order to identify key discursive themes (Berg, 2009; Leedy \& Ormrod, 2005). All data were coded for references to talent and talent management as the focus turned to the talent management discourse and analysis of what was used to bring the concepts of 'talent' and 'talent management' into existence as objects (Maguire, 2004). Within the larger study, data were separated according to: the concepts used to position the drivers and importance of talent management; the language used to construct meaning, to the concept of "talent"; and the language used to construct the meaning of the practice of talent management. It was within this activity that specific references to the process of talent identification were made and subsequent coding for this paper directed.

Discussions pertaining to talent identification were initially grouped into numerous categories of responses, also referred to in discursive studies as 'first order' codes (Maguire, 2004; Maguire \& Phillips, 2008) according to lexicon of terms which emanated from the data itself and a priori constructs (Eisenhardt, 1989) grounded in the existing literature. The terms used to represent these categories of responses, wherever possible, reflected the language used by executives or written texts. Many of these were most appropriately expressed via a simple descriptive phrase (Corley \& Gioia, 2004) rather than keywords. It was during this process that the constructs of 'measuring' (the identification of talent based on numerical measurements) and 'observing' (the identification of talent through observed activities and behavior) were revealed.

The third stage of analysis involved the creation of narratives in the organizational and business unit levels in order to collate and combine discourses within PSF's six business units with those operating at the organizational level. More specifically multiple accounts were juxtaposed against each other to ascertain the degree of convergence (Maguire \& Phillips, 2008) or divergence throughout the case organization. Composing of these 
narratives were important as they generated insights into the complex ways in which texts and discursive practices emerged and were embedded contextually (Francis et al., 2014).

The fourth and final stage of analysis involved a process of axial coding (Strauss \& Corbin, 1998). This stage of analysis focused on the identification of relationships and emerging patterns (Eisenhardt, 1989) between the categories of responses and the clustering of these responses into key discursive themes. These were further analyzed and then refined into theoretical categories, where like categories were combined (Corley \& Gioia, 2004). This was a systematic, abductive (Dubois \& Gadde, 2002; Wodak, 2004) and iterative process, where there was a continuous movement between the coding of the data, emerging themes, existing theory and the research until the patterns were refined into adequate conceptual categories (Eisenhardt, 1989). This permitted a synthesis that was anchored both empirically in the data and theoretically in the literature (Maguire \& Phillips, 2008). The data was triangulated within and across sources to identify potential divergences and convergences (Heracleous, 2006) across the organization. The focus here was on establishing insights which, when combined, were representative of multiple perspectives (Stake, 2006) and the opinions and experiences of stakeholders at a multiplicity of levels (executives, business units and the organization). Here two interrelated but divergent perspectives, referred to as 'Measuring' and 'Observing' discourses, are examined. In the sections that follow the 'measuring' and 'observing' talent identification processes at PSF, and the variation in the perceived usefulness of e-HRM in this specific talent management practice, are outlined.

\section{Case Study: Talent Identification Discourses at PSF}

PSF operates within the professional services industry and focuses on the delivery of knowledge and services to clients primarily located and operating within Australia. PSF's 6000 employees were located in offices around Australia, separated into six business units, 
with the value proposition of each underpinned by different client offerings including audit, tax, consulting, human capital and technology.

PSF was committed to talent management and believed that the effective management of talent was essential to wining the widely promoted 'war for talent' (Michaels, HandfieldJones, \& Axelrod, 2001). PSF recognized that the organization's ability to recruit and retain talented employees was significant for its success, with investments directed towards positioning the organization as a leader in the Professional Services Industry and an employer of choice. The services offered to clients were founded upon the knowledge and experience of its employees - and by direct consequence - its talent. Sentiments such as 'Our people are our most important asset' and '...talent is the firm's key source of competitive advantage' featured prominently with the executive leaders of PSF 'unapologetically put [ing] people at the apex of its business model'.

PSF operated without the guidance of a global or domestic (Australia) information technology strategy. The absence of mandated or strategically selected platforms encouraged the organization, including its HR function, to select and implement information technologies underpinned by a best-of-breed approach (Bedell \& Canniff, 2014) whereby technology platforms, including e-HRM platforms, were intentionally selected, implemented and appropriated based on specific needs and functionality.

...What [PSF] has done ... has been essentially to do a bit of a best of breed. So we'll select applications purpose fit for the functional need it's trying to achieve. Now that comes with a significant number of pitfalls because firstly you need to be able to manage - and in this case 80 applications in the firm and growing (Corporate HR executive).

This created a situation whereby the array of e-HRM was diverse with a number of different systems, including PeopleSoft (HRIS and people-based data), SuccessFactors (performance management), Saba, Cognos and Taleo (external recruitment), appropriated in relation to the 
management of people based resources with, as noted above, 80 systems operational throughout the organization. All of PSF's six business units were required to use a single system, SuccessFactors for performance management. When selected and implemented in 2008, SuccessFactors was perceived as more useful than an HRIS module of a larger vendor Enterprise Resource Planning system, because it was a niche product that specialised in human capital processes, including performance and goal management. The platform was a cost effective solution due to its structure as a licenced product and required little administrative support. Whilst this e-HRM platform was accessible for all senior executives to use in talent identification, there was evidence of variation in use, and adoption of alternate e-HRM platforms. The ability for the business unit's to enact agency over how e-HRM information technologies were used resulted from the absence of a mandated, or strategically selected, talent identification technologically enabled platform within PSF.

Despite variation in the use of SuccessFactors and other e-HRM information technologies to identify talent across PSF, there was agreement about which category of employees were indicative of "talent". All business units sought to identify individual employees who demonstrated the potential to be promoted to the role of partner, as they were of greatest strategic value and 'future leaders and future owners of the organization'. The purpose of talent identification, therefore, was to identify 'potential partners' within each of PSF's business units. Despite agreement about 'who' was talent, the absence of a firm-wide approach, ensured that the identification of talent was privy to the agency and interests of senior executives within each of PSF's six business units. The lack of consistent and mandated guidelines, criteria or evaluation methodologies meant that each business unit were able to self-determine the processes through which certain individuals would come to be referred to as "talent". 
Analysis of the texts revealed differences in the social processes through which individuals came to be considered as talent subjects. Whilst the talent management literature posits that talent are identifiable through either intuitive (unstructured and informal processes based on gut-feel), individualized (informal processes that focus on single individuals) or strategic (systematic, integrated and proactive processes applied consistently) processes business units debated whether talent should be identified through quantitative measurements or subjective observations. The axial stage of coding indicated that PSF's six business units did not seek an intermediary position, but rather offered the existence of two distinct, if interrelated discourses: a 'measuring' and an 'observing' discourse. Distinctions could be drawn between the perceived usefulness of e-HRM in each of these discourses.

The measuring discourse asserts that talent is a construct that can be quantified and 'measured'. This discourse was generated, sponsored and sustained by executives who seek to enact talent management through formalized and structured processes supported by eHRM. It specifies a range of specific organisational advantages that flow from the use of technology including: the ability to measure employee performance; facilitates formalized ranking process; framework to undertake workforce differentiation; standardized the defining characteristics of a talented employees; enactment of systemic and consistent talent identification processes underpinned by objective metrics.

The observing discourse tends to portray e-HRM more cautiously. Information technologies are seen to be of limited use within the talent identification processes as talent is a construct, which individual employees perform, and thus observed. Whilst e-HRM provides the capabilities to evaluate employee performance, and the implementation of a specific talent identification 'tool' or 'system' could ensure consistency across the organization, it also erects boundaries around the definition of talent. Such standardization, could in practice, limit the ability to recognise and reward a diversity of talent. 
The findings presented in the following sections will illustrate divergent opinions about the usefulness of e-HRM depending on whether stakeholders believed that 'potential partners' were best evaluated as talent subjects through a 'measuring' discourse - or through more subjective processes of observation - illustrated by the 'observing' discourse.

\section{The Usefulness of e-HRM when 'Measuring' Talent}

The 'measuring' discourse constructed "talent" as a concept that could be measured. This discourse advocated for talent identification objects that evaluated individuals according to pre-determined performance measures. These processes relied heavily on e-HRM to generate, analyze and distribute performance metrics, thus framing e-HRM as both useful and central to the evaluation, and thus measuring of employee performance. There were claims that e-HRM facilitated formalized and structured processes to rank employees and undertake workforce differentiation.

Measuring employee performance occurred via a two-stage process. The first stage, occurred during PSF's mandated annual performance review process in which all employees were allocated a 'score' out of 25. All senior executives, regardless of business unit, capitalized on the functionality of SAP's SuccessFactors to generate metrics about the performance of all employees. E-HRM was framed as valuable to this stage of the talent identification process as it "...enables the consistent evaluation of performance and potential of all employees across the organization" (Corporate HR executive).

In addition to evidence of the systematic use of a specific e-HRM platform (SuccessFactors) in the annual review process to quantifiably measure employee performance, its functionality could facilitate a formalized process to rank employees in relation to their status as "talent". Some business units sought to identify talent subsequent to the annual performance review by 'drawing a line' under the proportion of employees that 
they wanted to attribute the term talent. Executives noted that the performance based metrics generated as an output of the annual performance review process underpinned the ranking process. Whilst SuccessFactors provided all business units with this capability, it was seen as an imperative part of the talent identification process within the measuring discourse. E-HRM managed performance data such that high-performers and lists of potential talent subjects could be generated. . There was, however, substantial debate about what workforce percentage was to be categorized as "talent" with some executives suggesting $5 \%$ was the 'cutoff' in their business unit, whilst others suggested up to $30 \%$ of their workforce could be "talent".

Two business units proposed that the systematic evaluation of its workforce according to performance-based measures was the first of two stages. The second stage involved evaluating high-performing individuals according to their 'potential' as a future partner and successful admission into PSF's partnershipE-HRM capabilities, and the metrics generated, were used to construct a primary frame of reference for further, and more subjective, discussions about an employee's strategic value. In other words, whilst e-HRM standardized the evaluation of an employee's 'potential', the measures generated were privy to calibration sessions as senior executives subsequently debated the validity and perceived accuracy of performance measures.

Another business unit similarly positioned e-HRM as useful as it provided a framework to undertake workforce differentiation. The use of technology in provided a mechanism through which employees could be categorized, with high performing and high potential employees allocated to the 'top box'. In this way, e-HRM capabilities helped to "make sure that we have the right people in the top box..."(Business Unit Senior HR executive) 
E-HRM was of further value standardized the meaning of 'talent'. The use of e-HRM in talent identification, by design, required business units to agree upon the defining characteristics of talent within the context of its operations and strategic ambitions. These characteristics would act as the criteria upon which employees would be evaluated. E-HRM in this way, erected boundaries around 'what' skills and capabilities were embedded in talented employees. By consequence, the definition of talent was fixed, with the defining characteristics determined prior to initiating the process. For example, a senior HR executive noted that 'the use of a [talent identification] tool requires [senior executives and partners] to think about the definition of "talent" as this is needed in order to prescribe the criterion for evaluation'.

The identification of talent via pre-determined processes, enacted through information technology, was framed as useful within the measuring discourse for e-HRM acted as the mechanism to promote consistency within business units and across the organization. Standardizing the defining characteristics of a talented employee within the context of the dominant 'potential partner' concept, and documenting the valued skills and capabilities within e-HRM created an 'assessment methodology' that could be applied systematically. The elimination of localized idiosyncratic differences traditionally used by the different business units within the organization was a corollary of the push for standardization:

One of the single biggest factors driving it was to create some standardized assessment methodology. So that might perception of talent and your perception of talent were based on this framework. Yes definitely - big driver... So it was an agreed set of competencies or skills that would be desired... (Corporate Senior HR executive)

The standardization of the language and defining characteristics encompassed within the dominant talent concept featured prominently in the measuring discourses perceived usefulness of e-HRM because it would establish a 'robust' definition of talent. Most executives who prescribed to this discourse believed that the capabilities of e-HRM would 
lead to more effective talent identification practices because "...the key [to talent management] is having a robust definition to doing something with your talent" (Business Unit Senior HR executive). Many others reasoned that the introduction of processes embedded within e-HRM would result in a 'one-size-fits-all' approach whereby talent identification occurred through systematic and consistent processes.

Furthermore, basing decisions about an employee's inclusion, or exclusion, from the talent pool on pre-determined characteristics and processes enabled executives and business units to identify talent in an 'objective' manner. E-HRM was central to this discourse for it provided the capabilities to enact practices generated, maintained and analyzed by the IT system. Another prominent theme in the measuring discourse around the usefulness of eHRM information technologies was the assertion that quantitatively measuring employees, and thus talent, created a context where decisions could be 'transparent'. According to the discourse, effective talent identification, can only be fully realized when there is an ability to be open and transparent about how and why certain employees were identified as talent subjects:

As long as you manage it well and have a lot of communication around it and be open about the criteria and the reason why somebody is talent and why somebody is not marked as talent, there is always going to be people that feel left out. (Business Unit Senior HR executive)

Despite the apparent link between the efficiency and effectiveness gains allegedly associated with e-HRM and the opportunities this provided for standardization in the language and processes of talent identification, the measuring discourse evidenced an ambivalence towards the prospect of reductions in the ability to recognize and reward a diverse array of employees. Questions were raised about the potential narrowing of the defining characteristics of talent whereby evaluating employees according to the same criteria, and via systemic and consistent processes, could result in the identification of "talent 
clones". The potential inability to have a diversity of talent within the organization was of paramount concern for PSF's CEO. This key stakeholder, referred to 'talent clones' and discursively framed a measures-based approach as limiting and ineffective. Several executives referred to the $\mathrm{CEO}$ when discussing the potential limitations of their existing processes, for example:

...From a talent perspective and I know that it is something that our capability team has had a challenge that [the CEO] thinks and has a view that you cannot just say that talent fit into this box or that box. They are all different and it is all different. (Business Unit Senior HR executive)

The discursive framing of the potential limitations associated with e-HRM ignited hesitations and concerns about the effectiveness of basing decisions about which employees were indicative of talent solely on quantitative measures appeared to legitimize the alternative 'observing' discourse with evidence that the two talent identification discourses were positioned alongside each other.

\section{The Usefulness of e-HRM when 'Observing' Talent}

Analysis of texts indicated that there was a second set of policies and processes adopted within PSF to identify talent subjects. These processes sought not to quantitatively measure an employee's value through the capabilities of e-HRM but rather emphasized subjective evaluations and observations. In stark contrast with the desire to identify talent via systematic processes founded on quantitative measures, this approach advocated flexible and tailored processes underpinned by the belief that "talent" was an observable attribute, with talent subjects effectively identified through subjective evaluations and collegiate discussions. Talent was identified, not via a ranking process, but rather through consensus. This discourse appears to be driven and sustained by two key forces - that talent is an attribute that stakeholders can 'see', and the desire to avoid a homogeneous cohort of talent subjects. 
Within the discourse, senior executive agency was positioned as pivotal and e-HRM framed as playing a more supporting role in the processes of talent identification.

There was evidence of the observational approach being the dominant, and preferred, practice at PSF. An observational approach was, many executives and business unit's posited, helpful in ensuring that valuable employees, and talent subjects, were identified via a practice which was underpinned by an array of data, information and senior executive knowledge. There was evidence that many parts of PSF were concerned about the negative implications of identifying talent based on measures, scores, or ranks. There was also the assertion that talent was effectively evaluated through observations therefore limiting the need for 'structured' processes:

... There are some groups in [PSF] ... who have a much more structured approach, who have a tool, that you know you could put millions of things in and spit out results... [but there are others] because of the nature of their work that style doesn't really work for them. They are like, well I will just tell you who my top talent is. And I say, you know what, I don't believe that we need to over engineer it, and spend 8 hours to come up with a result of who our talent is. (Business Unit Senior HR executive)

The perceived usefulness of e-HRM appeared to center specifically on the ability for information technology to evaluate employee performance and facilitate the identification of high performing individuals. The functionality of e-HRM, and more specifically SuccessFactors, was therefore afforded comparable value within both the measuring and observing discourse in this way, however, further discussions were accompanied by concerns and reservations about the implications associated with standardizing the defining characteristics of talent and the processes of talent identification.

This discourse was premised upon the assumption that the concept of "talent" is identifiable and observable, with the language of 'seeing' talent featuring prominently. The overwhelming majority of executives, who prescribed to the observing discourse, indicated that "talent" was an attribute embedded in individuals, with talented employees acting in a 
positive manner. Therefore, talent was a construct that individual employees performed, they demonstrated and hence an attribute which others could see and observe. Whilst e-HRM was useful in identifying such talent subjects because it generated employee performance data, it was not able to effectively evaluate and determine employee 'potential'. Rather than asserting that measures were generated, captured and analyzed through e-HRM, the observing discourse framed e-HRM of limited use, as they were able to 'see' talent. For example, senior executives within two business units that prescribed to these processes explained that "People within the business should be open to seeing talented people" (Business Unit Senior Executive) and "...you will be able to see the top $10 \%$ and the stellar talent" (Business Unit Senior Executive). These beliefs coupled with the opinions of the CEO ensured the legitimacy of this discourse throughout the organization.

From this perspective, senior executives and senior partners involved in talent identification possessed the skills and capabilities to determine which employees were of the greatest value and indicative of the future leaders and future partners of the organization. Human actors, rather than e-HRM, housed the capacity to evaluate and judge an employee's ability to be promoted to the most senior levels of PSF. This was, as the following quotation illustrates, due to the experiences of these senior executives and their knowledge and 'insight' into defining characteristics required of talent subjects in order to facilitate successful promotions, because they themselves had been subjected to this process:

Those people that have gotten to the top have tended to have an intrinsic insight into what it takes to get there so they are able to see these traits or behaviors or abilities in others. So they tend to overlay their own experience when they are actually identifying who we think are [talent]. (Business Unit Senior HR executive)

While one business unit had investigated e-HRM platforms and their ability to enhance the effectiveness of current observational processes, the potential value was deemed 
negligible, because 'open' conversations between key stakeholders about potential talent subjects were of greater value:

The other things that we have looked at... is the way technology is helping organizations manage talent. We haven't seen too much which helps them identify who the talent are apart from some add-ons to some automated performance management systems. But it still comes back to having a discussion, using a model, and having a discussion of the people, with the right people, who expert in people who can then identify who those people are. (Business Unit Senior HR executive)

The observing discourse portrays e-HRM as ineffective in identifying talent. Executives complained that processes, which utilized the capabilities of information technologies, might create a situation where the inclusion or exclusion of employees from the talent pool resided in the opinions of the senior executive responsible for the evaluation process. There was also the belief that such processes were more effective in ensuring that the 'right' employees were identified as talent subjects since there was the potential that the measurements generated through e-HRM and a talent identification technologically enabled 'tool' or 'system' may be founded upon a single opinion, captured and documented at a single point of time.

The problems associated with e-HRM also extended to the notion of inflexibility. The problems with inflexibility were associated with the requirements of e-HRM to standardize the meaning of talent. Predefining the skills and capabilities required of talented employee, and enacting talent identification via structured and consistent process, may result in the identification of 'talent clones'. The observing discourse contends that e-HRM is fundamentally limited in the ability to recognise and reward a diverse array of skills and capabilities within business units and across the organization, for information technologies facilitate, promote and support a one-size-fits-all approach to talent. Flexible and fluid talent identification processes, founded upon observations, were more effective. 
The implicit force which sustained the observing discourse was the threat posed by eHRM systems and its processes to the autonomy, discretion and power of senior executives responsible for identifying talent. The discourse indicated that there was an awareness that more 'structured' set of processes would hinder the ability to ensure that powerful stakeholders were actively involved in the object of talent identification. There was the potential that the use of technologically enabled processes would be detrimental:

But in a partnership if it involves partners getting involved in going through a very long process to identify [talent], then they will soon get bored of it...in the process we are running now I get a good enough outcome which keeps them [partners] engaged and gives me an outcome. Whereas if I move towards probably a more robust identification process, I am not going to get that partner buy-in and I will probably end up with a worse result at the end. (Business Unit Senior HR executive)

Advocates of the observing discourse were conscious that the absence of a predetermined or structured methodology could result in processes that focused on the needs of the respective business units, rather than those of the organization as a whole. In this way, the use of e-HRM in talent identification could ensure that all of PSF's business units were 'doing the same thing'. Information technologies could also ensure that processes were integrated, informed by and strategically aligned to, both business unit and organizational ambitions. Despite the presence of these concessions within the observing discourse, the ability to identify a diversity of talent remained paramount.

\section{Summary}

By examining the perceived usefulness of e-HRM within the context of talent identification at PSF, this study provides for a richer and more comprehensive understanding of the ways in which an array of stakeholders (executives and business units) frame the role of e-HRM. The application of discourse analysis to the texts used by key stakeholders in the case organization facilitates the development of a more nuanced, in-depth understanding of the relationship between e-HRM and talent management. More specifically, this approach 
enabled the examination of the complex and divergent ways that executives and business units identified talent subjects. It also highlighted that the perceived usefulness of e-HRM in talent identification varied in accordance with the measuring or observing discourse. The study, therefore, offers empirical insights that suggest that these talent identification discourses had implications for the way in which stakeholders made sense of e-HRM and how the technology shaped, and were shaped by, the talent identification practices.

Whilst employees at PSF were not subjected to the same identification process (Iles et al., 2010; Stainton, 2005) or evaluated according to consistent organization-wide criteria (Busine \& Watt, 2005), the findings revealed that the measuring discourse framed e-HRM as useful for talent identification. This discourse asserted that 'talent' was a construct embedded in individual employees which was quantitatively measureable. This discourse prioritizes eHRM capabilities as they enabled stakeholders to generate, analyze and distribute performance metrics. This discourse, enabled through e-HRM, was structured around 'formalized', 'standardized, 'consistent' and 'objective' processes. The measuring discourse framed e-HRM as the mechanism through which both the performance and potential of an employee was evaluated and thus 'measured'. Capabilities to generate data and measures about employees were critical, placing information technology in a central role. Of particular note was the assertion that it was via proprietary based e-HRM, whether referred to as a talent identification 'tool' or 'system', that the definition of talent could be standardized. Establishing a fixed understanding of talent subjects, was the basis for the enactment of systematic processes. Such processes, were viewed as objective and afforded executives with the ability to make talent identification visible and transparent. However, the power and influence of this measuring discourse, was influenced by its capacity to persuade others of its usefulness and legitimacy. Whilst this discourse was pervasive, conducting talent 
identification in this way might privy similarity and consistency, which would result in talent clones (McDonnell, 2011), rather than a diversity of talent.

Confronted by concerns about the detrimental implications of a systematic process founded upon data and metrics, many executives and business units sought to identify talent through a process of observation and "seeing". The observing discourse, whilst similarly asserting that talent is a construct embedded in individual employees, was underpinned by the belief that talent could be observed. This discourse prioritized senior executive agency, knowledge and experience as subjective and observational based evaluations to facilitate flexible and fluid talent identification processes. E-HRM capabilities focused on evaluating employee performance and ensuring consistently across the organization. This approach called for a flexible and tailored process and was premised on the belief that the value of an employee was determined through subjective evaluations of that individuals 'potential' to be admitted into PSF partnership. This discourse tended to be more future focussed, drawing on perceptions of senior executives and partners to assess current performance and predict future capabilities and contributions. The discourse framed e-HRM in a support role and whilst there was evidence that the functionality of technology was utilized as the means to evaluate 'performance', this process relied on human, rather than technology actors. The standardization of the meaning of talent required by technology was not only undesirable, but also considered less effective in the realization of the proclaimed benefits of talent management.

By analyzing the discourses around talent identification and management at PSF the study was able to generate valuable insights into the role of e-HRM and to gain a more nuanced understanding of the way in which e-HRM was framed and enacted differently throughout the organization. The two contrasting talent identification practices were not indicative of processes that were ad-hoc or underpinned by the instinct and intuition of one 
executive (Bassi \& McMurrer, 2007; McDonnell et al., 2010), but rather well defined. Despite providing evidence which confirmed the value of e-HRM because it facilitated a standardized (Parry \& Tyson, 2011), or consistent talent identification practice, the case study illustrated that discourses about the value of e-HRM were not, as many e-HRM discourses would have assumed, positioned in relation to the need to facilitate faster and more accurate decision making (Parry \& Tyson, 2011; Ruël et al., 2004; Schalk et al., 2013). This was despite, talent management and talent identification being recognized by PSF as transformational activities (Parry \& Tyson, 2011; Thite \& Kavanagh, 2009). The discourses about e-HRM were not necessarily confined to, or positioned in relation to the functionality of the technology, and the inability to capitalize or realize the benefits of the e-HRM platform (Grant, Dery, Hall, Wailes, \& Wiblen, 2009; Wiblen et al., 2012). Rather, they were influenced by the power and agency of senior executives and their preferred approach to talent identification. Advocates of the 'observing' talent approach, afforded very little salience to the access to data (Schalk et al., 2013; Stone \& Dulebohn, 2013; Williams, 2009) nor the generation and application of metrics to make decisions about the key resource of “talent” (Bassi \& McMurrer, 2007; Boudreau \& Ramstad, 2002; Williams, 2009).

\section{Contributions to Scholarship}

This study, through the theoretical lens of discourse analysis, enhances our understanding of the usefulness of e-HRM in talent management in a number of significant ways. First, it examines the intersection of two social phenomena, e-HRM and talent management, where, despite continued rhetoric about the importance of both technology and talent management to organizations, empirical and theoretical contributions, particularly those which view e-HRM as a process rather than a deterministic feature of organizing, are considered to be nominal and lacking (Marler \& Fisher, 2013; Stone \& Dulebohn, 2013). Second, by applying discourse analysis, the study is able to offer insights into the complex social practices 
associated with both talent management and e-HRM that quantitative studies cannot easily reveal. The study has presented evidence of the existence of two distinct, but interrelated talent identification discourses, and how both sets of processes can be viewed as legitimate (Vaara, Kleymann, \& Seristö, 2004). This study goes further in identifying how discourses of talent identification come to bear down on e-HRM. In other words, the study shows that the influence of e-HRM in organizations, and talent management are not deterministic, but rather subjected to an ongoing process of negotiation, whereby 'measuring' and 'observing' approaches, and divergent interpretations of e-HRM, were simultaneously 'ruled in' (Hall, 2001; Phillips et al., 2004) within the boundaries of one organization. By doing so, the study contributes to a more comprehensive understanding of e-HRM by offering empirical evidence which indicates that stakeholders within PSF drew upon frames imported from talent identification processes, and assumptions about whether talent should be identified through processes of quantitative measurement or observations, in order to interpret e-HRM information technology (Leonardi \& Barley, 2010). Third, by critically examining the discourses that frame and influence talent identification it illustrates how interactions between information technologies and the users shaped the understanding and enactment of e-HRM in talent management. By opening up and examining the discursive space of PSF, the findings offer new insights which enhance our understanding of the perceived usefulness of e-HRM within organizational contexts. Specifically, the study shows that whilst stakeholders confirmed what many other information systems studies have found (Davis, 1989; Davis et al., 1989; Marler et al., 2009; Venkatesh et al., 2003), that using a particular system would enhance job performance, the perceived usefulness of e-HRM at PSF viewed the capabilities as central to systematic and standardized talent identification processes. The study was also able to show that others framed this same capability as detrimental as the use of e-HRM, by design, requires the standardization of the meaning of talent, as well as the processes of talent 
identification. Such inflexibility could, it was posited in the observing discourse, limit the ability to recognize a diversity of talent. In doing so, the study, illustrates not only that eHRM was positioned as useful, but also 'how' and 'why' information technologies were framed as both helping and hindering effective talent identification. These insights are currently absent in existing e-HRM and talent management publications.

\section{Applied Implications}

The contribution of the study at a more practical level is to encourage conversations between HR practitioners, line managers and academics about the challenges associated with e-HRM and the relationship between technology and talent identification more specifically. While this study has indicated that e-HRM platforms are of value to talent identification, it also indicated the need for open dialogue between stakeholders about the structure and composition of talent identification processes. As was noted earlier, there are cautionary concerns associated with standardizing the processes enacted to identify talent subjects. These were encased with the desire to either ensure objectivity in the process, whilst others debated the value of this in relation to beneficial talent management outcomes. The contested nature of information technology foregrounds the role of language, and the importance of collegial conversations to establish convergence, rather than divergence, in the role and usefulness of e-HRM. Furthermore, while the findings did not indicate that talent identification practices were ad hoc, they were informed by local practices (Burbach \& Royle, 2010), with little evidence of a strategic organization-wide (Collings \& Mellahi, 2009; Whelen \& Carcary, 2011), or systems-based (Beechler \& Woodward, 2009; Jones et al., 2012; Stahl et al., 2007) approach to talent management at PSF. Whilst senior executives may declare that talent management requirements differ within organizational boundaries, it is argued that practitioners should proactively address the needs of stakeholders and ensure that talent management practices, including talent identification, are informed by, and aligned to 
an organization's strategic ambition. This needs to occur in ways that are deliberate, intentional and cross-divisional, rather than through informed ambiguity. Furthermore, despite previous suggestions that organizations, such as PSF, may not be using e-HRM in talent management because of the limited mathematical abilities and knowledge of HR professionals (Wiblen et al., 2012), there was no evidence of these sentiments in PSF as executives did not refer to the presence, nor absence of such skills, in either discourses. Despite this, HR professionals, and other key stakeholders should proactively recruit for, or develop such skills, otherwise the capabilities, functionality and potential benefits of e-HRM will, by consequence, remain underutilized. While the mechanisms through which to effectively measure and objectively evaluate an employee 'potential' remains elusive, it is essential that organizations seek to generate and apply talent based metrics, data and analytics to ensure that decisions about talent are based, to some extent, on evidence. It is through evidence-based management that organizations can ensure alignment between the appropriation of e-HRM the identification of talent and the realization of broader strategic goals.

\section{Limitations and Future Research Directions}

The study has a number of limitations. First, in adopting a single site exploratory case study to examine talent management, caution must be applied if attempting to draw wider generalizations because of the context specific nature of the findings, which seek to illuminate and provide thick descriptions (Geertz, 1973) rather than internal validity. Furthermore, although the study offers empirical insights into the 'how' executives talked about the usefulness of e-HRM in talent identification, the findings can only be understood and articulated within particular spatial and temporal contexts (Grant \& Shields, 2006). Therefore, further exploration of the role and value attributed to e-HRM and metrics in other organizations represent fruitful contexts for future research, and may enhance our knowledge 
of the functionality of e-HRM platforms in human resource, and talent management practices. The study, by providing empirical evidence that indicates that talent management, and more specifically talent identification, can be the subject of contestation and power relations even within the one organization, indicates examination of the role of power and politics in talent management warrants further investigation. 


\section{References}

Bassi, L., \& McMurrer, D. (2007). Maximizing Your Return on People Harvard Business Review, 1-10.

Bedell, M. D., \& Canniff, M. L. (2014). Systems Considerations in the Design of a Human Resource Information System: Planning for Implementation. In M. J. Kavanagh, M. Thite, \& R. D. Johnson (Eds.), Human Resource Information Systems: Basics, Applications, and Future Directions. (3rd ed., pp. 57-81). Thousand Oaks, California: SAGE Publications Inc. .

Beechler, S., \& Woodward, I. C. (2009). The global "war for talent". Journal of International Management, 15(3), 273-285.

Berg, B. L. (2009). Qualitative Research Methods for the Social Sciences (7th ed.). Boston: Allyn \& Bacon

Björkman, I., Smale, A., Sumelius, J., Suutari, V., \& Lu, Y. (2008). Changes in institutional context and MNC operations in China: Subsidiary HRM practices in 1996 versus 2006. International Business Review, 17(2), 146-158.

Blass, E. (2007). Talent Management: Maximising talent for business performance. Executive Summary November 2007 (pp. 1-12). London: Chartered Management Institute \& Ashbridge Consulting.

Boudreau, J. W. (2003). Sustainability and the Talentship Paradigm: Strategic Human Resource Management Beyond the Bottom Line (CAHRS Working Paper 03-21).

Boudreau, J. W., \& Ramstad, P. M. (2002). Strategic HRM measurement in the 21st Century: From Justifying HR to Strategic Talent Leadership (CAHRS Working Paper 02-15).

Burbach, R., \& Royle, T. (2010). Talent on demand?: Talent management in the German and Irish subsidiaries of a US multinational corporation. Personnel Review, 39(4), 414431. 
Busine, M., \& Watt, B. (2005). Succession management: Trends and current practice. Asia Pacific Journal of Human Resources, 43(2), 225-237.

Calo, T. J. (2008). Talent Management in the Era of the Aging Workforce: The Critical Role of Knowledge Transfer. Public Personnel Management, 37(4), 403-416.

Capelli, P. (2008). Talent Management for the Twenty-First Century. Harvard Business Review, 86, 74-81.

Carabine, J. (2001). Unmarried motherghood 1830-1990: a genealogical analysis In M. Wetherell, S. Taylor, \& S. J. Yates (Eds.), Discourse as Data: A Guide for Analysis (pp. 267-310). London: Sage Publications

Chambers, E. G., Foulton, M., Handfield-Jones, H., Hankin, S. M., \& Michaels Ill, E. G. (1998). The War For Talent McKinsey Quarterly(3), 44-57.

CIPD. (2006). Talent Management: Understanding the Dimensions In C. I. o. P. a. D. (CIPD) (Ed.), Change Agenda. London: Chartered Institute of Personnel and Development

Collings, D. G., McDonnell, A., \& Scullion, H. (2009). Global Talent Management: The Law of the Few Poznan University of Economics Review, 9(2), 5-18.

Collings, D. G., \& Mellahi, K. (2009). Strategic talent management: A review and research agenda. Human Resource Management Review, 19(4), 304-313.

Corley, K. G., \& Gioia, D. A. (2004). Identity Ambiguity and Change in the Wake of a Corporate Spin-off. Administrative Science Quarterly, 49(2), 173-208.

Davenport, T., Harris, J., \& Shapiro, J. (2010). Competing on Talent Analytics. Harvard Business Review, 88(10), 53-58.

Davis, F. D. (1989). Perceived Usefulness, Perceived Ease of Use, and User Acceptance of Information Technology. MIS Quarterly, 13(3), 319-340.

Davis, F. D., Bagozzi, R. P., \& Warshaw, P. R. (1989). User Acceptance Of Computer Technology: A Comparison Of Two. Management Science, 35(8), 982. 
Devine, M., \& Powell, M. (2008). Talent management in the public sector 360 The Ashridge Journal(Autumn 2008), 1-6.

Dries, N. (2013). The psychology of talent management: A review and research agenda. Human Resource Management Review, 23(4), 272-285.

Dubois, A., \& Gadde, L.-E. (2002). Systematic combining: an abductive approach to case research. Journal of Business Research, 55, 553-560.

Eisenhardt, K. M. (1989). Building Theories from Case Study Research. Academy of Management Review, 14(4), 532-550.

Fairclough, N. (1992). Discourse and social change. Cambridge: Polity Press.

Fairclough, N. (1995). Critical Discourse Analysis: The Critical Study of Language. London: Longman.

Farndale, E., Paauwe, J., \& Hoeksema, L. (2009). In-sourcing HR: shared service centres in the Netherlands. International Journal of Human Resource Management, 20(3), 544561.

Francis, H., Parkes, C., \& Reddington, M. (2014). E-HR and international HRM: a critical perspective on the discursive framing of e-HR. The International Journal of Human Resource Management, 25(10), 1327-1350.

Geertz, C. (1973). Thick Description: Towards an Interpretive Theory of Culture The Interpretation of Cultures: Selected Essays (pp. 3-30). New York: Basic Books

Grant, D., Dery, K., Hall, R., Wailes, N., \& Wiblen, S. (2009). Human Resource Information Systems (HRIS): An Unrealised Potential Paper presented at the Annual CIPD Centres' Conference Nottingham, United Kingdom

Grant, D., \& Marshak, R. J. (2011). Toward a Discourse-Centered Understanding of Organizational Change. The Journal of Applied Behavioral Science, 47(2), 204-235. 
Grant, D., \& Shields, J. (2006). Identifying the Subject: Worker Identity as Discursively Constructed Terrain In M. Hearn \& G. Michelson (Eds.), Rethinking Work: Time, Space and Discourse (pp. 285-307). Melbourne, Australia: Cambridge University Press.

Hall, S. (2001). Foucault: Power, Knowledge and Discourse. In M. Wetherell, S. Taylor, \& S. J. Yates (Eds.), Discourse Theory and Practice: A Reader (pp. 72-81). London: SAGE Publications

Hardy, C., Lawrence, T. B., \& Grant, D. (2005). Discourse and Collaboration: The Role of Conversations and Collective Identity. Academy of Management Review, 30(1), 5877.

Hardy, C., \& Phillips, N. (2004). Discourse and Power. In D. Grant, C. Hardy, C. Oswick, \& L. Putnam (Eds.), Handbook of Organizational Discourse (pp. 299-316). London: SAGE Publications

Hartmann, E., Feisel, E., \& Schober, H. (2010). Talent management of western MNCs in China: Balancing global integration and local responsiveness. Journal of World Business, 45(2), 169-178.

Heller, M. (2003). Globalization, the new economy, and the commodification of language and identity. Journal of Sociolinguistics, 7(4), 473-492.

Heracleous, L. (2006). A Tale of Three Discourses: The Dominant, the Strategic and the Marginalized. Journal of Management Studies, 43(5), 1059-1087.

Highhouse, S. (2008). Stubborn Reliance on Intuition and Subjectivity in Employee Selection. Industrial and Organizational Psychology, 1(3), 333-342.

Horibe, F. (1999). Managing knowledge workers: New skills and attitudes to unlock the intellectual capital in your organization. Toronto: John Wiley and Sons 
Huselid, M. A., Beatty, R. W., \& Becker, B. E. (2005). "A Players" or "A Positions"? The Strategic Logic of Workforce Management. Harvard Business Review (December 2005), 110-117.

Iles, P., Chuai, X., \& Preece, D. (2010). Talent Management and HRM in Multinational companies in Beijing: Definitions, differences and drivers. Journal of World Business, 45(2), 179-189.

Jones, J. T., Whitaker, M., Seet, P.-S., \& Parkin, J. (2012). Talent management in practice in Australia: individualistic or strategic? An exploratory study. Asia Pacific Journal of Human Resources, 50(4), 399-420.

Lawler, E., Levenson, A., \& Boudreau, J. W. (2004). HR Metrics and Analytics: Use and Impact. Human Resource Planning, 27(4), 27-35.

Leedy, P. D., \& Ormrod, J. E. (2005). Practical Research: Planning and Design New Jersey: Pearson Education

Leonardi, P. M., \& Barley, S. R. (2010). What's Under Construction Here? Social Action, Materiality, and Power in Constructivist Studies of Technology and Organizing. The Academy of Management Annals, 4(1), 1-51.

Lewis, R. E., \& Heckman, R. J. (2006). Talent management: A critical review. Human Resource Management Review, 16(2), 139-154.

Maguire, S. (2004). The Co-Evolution of Technology and Discourse: A Study of Substitution Processes for the Insecticide DDT. Organization Studies, 25(1), 113-134.

Maguire, S., \& Hardy, C. (2009). Discourse and Deinstitutionalization: The Decline of DDT Academy of Management Journal, 52(1), 148-178.

Maguire, S., \& Phillips, N. (2008). 'Citibankers' at Ciigroup A study of the Loss of Institutional Trust after a Merger Journal of Management Studies, 45(2), 372-401. 
Mäkelä, K., Björkman, I., \& Ehrnrooth, M. (2010). How do MNCs establish their talent pools? Influences on individuals' likelihood of being labeled as talent. Journal of World Business, 45(2), 134-142.

Marler, J. H., \& Fisher, S. L. (2013). An evidence-based review of e-HRM and strategic human resource management. Human Resource Management Review, 23(1), 18-36.

Marler, J. H., Fisher, S. L., \& Ke, W. (2009). Employee Self-Service Technology Acceptance: A Comparision of Pre-Implementation and Post-Implementation Relationships. Personnel Psychology, 62(2), 327-358.

Marshall, C., \& Rossman, G. B. (1995). Designing Qualitative Research (2nd ed.). Thousand Oaks, London, New Delhi SAGE Publications

McDonnell, A. (2011). Still Fighting the War for Talent? Bridging the Science Versus Practice Gap. Journal of Business and Psychology, 26(2), 169-173.

McDonnell, A., Lamare, R., Gunnigle, P., \& Lavelle, J. (2010). Developing Tomorrow's Leaders- Evidence of Global Talent management in Multinational Companies Journal of World Business, 45(2), 150-160.

Mellahi, K., \& Collings, D. G. (2010). The barriers to effective global talent management: The example of corporate élites in MNEs. Journal of World Business, 45(2), 143-149.

Michaels, E., Handfield-Jones, H., \& Axelrod, B. (2001). The War for Talent Boston: Harvard Business School Press.

Parker, I. (1992). Discourse dynamics: Critical analysis for social and individual psychology London: Routledge

Parry, E., \& Tyson, S. (2011). Desired goals and actual outcomes of e-HRM. Human Resource Management Journal, 21(3), 335-354.

Phillips, N., Lawrence, T. B., \& Hardy, C. (2004). Discourse and Institutions Academy of Management Journal, 29(4), 635-652. 
Potter, J., \& Wetherell, M. (1987). Discourse and Social Psychology: Beyond Attitudes and Behaviour. London: Sage Publications.

PwC. (2014). The talent challenge: Adapting to growth.

Roulston, K., deMarrais, K., \& Lewis, J. B. (2003). Learning to Interview in the Social Sciences. Qualitative Inquiry, 9(4), 643-668.

Rousseau, D. M., \& Barends, E. G. R. (2011). Becoming an evidence-based HR practitioner. Human Resource Management Journal, 21(3), 221-235.

Ruël, H., Bondarouk, T., \& Looise, J. (2004). E-HRM: Innovation or Irritation. An Explorative Empirical Study in Five Large Companies on Web-based HRM Management Revue, 15(3), 364-380.

Schalk, R., Timmerman, V., \& den Heuvel, S. v. (2013). How strategic considerations influence decision making on e-HRM applications. Human Resource Management Review, 23(1), 84-92.

Schweyer, A. (2004). Talent management systems: Best practices in technology solutions for recruitment, retention and workforce planning. New Jersey: John Wiley and Sons.

Stahl, G. K., Björkman, I., Farndale, E., Morris, S. S., Paauwe, J., Stiles, P., . . Wright, P. M. (2007). Global Talent Management: How Leading Multinationals Build and Sustain Their Talent Pipeline. INSEAD Working Papers Collection(34), 1-36.

Stainton, A. (2005). Talent management: Latest buzzword or refocusing existing processes? . Competency and Emotional Intelligence, 12(1), 39-43.

Stake, R. E. (2006). Multiple Case Study Analysis. New York: The Guilford Press.

Stone, D. L., \& Dulebohn, J. H. (2013). Emerging issues in theory and research on electronic human resource management (eHRM). Human Resource Management Review, 23(1), $1-5$. 
Strauss, A. L., \& Corbin, J. M. (1998). Basics of qualitative research : techniques and procedures for developing grounded theory (J. M. Corbin, Trans. 2nd ed.). Thousand Oaks Sage Publications.

Tansley, C. (2011). What do we mean by the term "talent" in talent management? Industrial and Commercial Training, 43(5), 266-274.

Tarique, I., \& Schuler, R. S. (2010). Global talent management: Literature review, integrative framework, and suggestions for further research. Journal of World Business, 45(2), $122-133$.

Thite, M., \& Kavanagh, M. J. (2009). Evolution of Human Resource Management and Human Resource Information Systems: The Role of Information Technology. In M. Thite \& M. J. Kavanagh (Eds.), Human Resource Information Systems. Basics, Applications, and Future Directions (pp. 3-24). California: SAGE Publications INC.

Thunnissen, M., Boselie, P., \& Fruytier, B. (2013a). A review of talent management: 'infancy or adolescence?'. The International Journal of Human Resource Management, 24(9), 1744-1761.

Thunnissen, M., Boselie, P., \& Fruytier, B. (2013b). Talent management and the relevance of context: Towards a pluralistic approach. Human Resource Management Review, 23(4), 326-336.

Towers Watson. (2010). Global Workforce Study 2010.

Vaara, E., Kleymann, B., \& Seristö, H. (2004). Strategies as Discursive Constructions: The Case of Airline Alliances. Journal of Management Studies, 41(1), 1-35.

Van de Ven, A. H., \& Poole, M. S. (1990). Methods for Studying Innovation Development in the Minnesota Innovation Research Program Organization Science, 1(3), 313-335.

van Dijk, T. A. (1997). Discourse as interaction in society. In T. A. van Dijk (Ed.), Discourse as Social Interaction (pp. 1-37). London: SAGE Publications 
Venkatesh, V., Morris, M. G., Davis, G. B., \& Davis, F. D. (2003). User acceptance of information technology: Toward a unified view. MIS Quarterly, 27(3), 425-478.

Vorster, G. (2008). Tick-Box Mentality Explains Poor Take Up of Appraisals in UK. Personnel Today.

Wellins, R. S., \& Schweyer, A. (2007). Talent Management in Motion: Keeping Up with an Evolving Workforce: Executive Summary.

Whelen, E., \& Carcary, M. (2011). Integrating talent and knowledge management: where are the benefits? . Journal of Knowledge Management, 15(4), 675-687.

Wiblen, S., Dery, K., \& Grant, D. (2012). Do you see what I see? The role of technology in talent identification. Asia Pacific Journal of Human Resources, 50(4), 421-438.

Wiblen, S., Grant, D., \& Dery, K. (2010). Transitioning to a New HRIS: The Reshaping of Human Resources and Information Technology Talent Journal of Electronic Commerce Research, 11(4), 251-267.

Williams, H. (2009). Job Analysis and HR Planning. In M. Thite \& M. J. Kavanagh (Eds.), Human Resource Information Systems. Basics, Applications, and Future Directions (pp. 251-276). California: SAGE Publications Inc.

Wilson, P. (2010). people@work/2020: The Future of Work and the Changing Workplace: Challenges and Issues for Australian HR Practitioners. In A. H. R. Institute (Ed.). Melbourne

Wodak, R. (2004). Critical Discourse Analysis. In C. Seale, D. Silverman, J. F. Gubrium, \& G. Gobo (Eds.), Qualitative Research Practice: Concise Paperback Edition (pp. 185202). London: SAGE Publications Ltd. 